\title{
Growth inhibition of both MCF-7 and Hs578T human breast cancer cell lines by vitamin $D$ analogues is associated with increased expression of insulin-like growth factor binding protein-3
}

\author{
K W Colston, C M Perks*, S P Xie and J M P Holly*
}

Division of Gastroenterology, Endocrinology and Metabolism, St George's Hospital Medical School, London SW17 ORE and *Division of Surgery Department of Hospital Medicine, Level 7, Bristol Royal Infirmary, Marlborough Street, Bristol BS2 8HW, UK

\begin{abstract}
The effects of two vitamin D analogues, EB1089 and CB1093, on insulin-like growth factor binding protein (IGFBP) expression have been examined in MCF-7 and Hs578T human breast cancer cell lines. Both vitamin D analogues inhibited IGF-I stimulated growth of MCF-7 cells and enhanced the production of IGFBP-3 as determined by Western-ligand blotting. Recombinant human IGFBP-3 inhibited the growth of MCF-7 cells over the concentration range $1-235 \mathrm{ng} / \mathrm{ml}$. Hs578T cells were unresponsive to the mitogenic effects of
\end{abstract}

IGF-I but growth was inhibited by the two vitamin D analogues. Treatment of Hs578T cells with EB1089 and CB1093 (10 nM) as well as $100 \mathrm{nM}$ 9-cis retinoic acid (9-cis RA) or all-trans retinoic acid (ATRA) was associated with increased accumulation of IGFBP-3 in conditioned medium. Furthermore, cotreatment of Hs578T cells with EB1089 and 9-cis RA led to augmented effects on both inhibition of cell growth and IGFBP-3 accumulation in conditioned medium as assessed by Western ligand blotting and radioimmunoassay. These findings suggest a role for IGFBP-3 in the growth inhibitory effects of vitamin $D$ analogues.

\section{Introduction}

The active form of vitamin $\mathrm{D}, 1,25$-dihydroxyvitamin $\mathrm{D}_{3}$ $\left(1,25(\mathrm{OH})_{2} \mathrm{D}_{3}\right)$, has been shown to possess many properties unrelated to its classical functions as a regulator of bone and mineral metabolism. While the role of $1,25(\mathrm{OH})_{2} \mathrm{D}_{3}$ as an agent which inhibits proliferation of breast cancer cells is now well recognised, its use in cancer treatment is precluded by its potent calcaemic activity. Vitamin D analogues have been synthesised which retain the ability to control cell proliferation but display reduced calcaemic activity. Certain of these compounds markedly inhibit the growth of cultured breast cancer cells and cause regression of experimental mammary tumours in vivo (Abe et al. 1991, Colston et al. 1992). However, the precise mechanism of action of these new compounds remains unclear.

Breast cancer cells both secrete and respond to a variety of peptide growth factors. The growth in culture of many established human breast cancer cell lines is stimulated by the insulin-like growth factors (IGFs I and II): in the case of the MCF-7 cell line, IGF-I has been reported to be the most potent mitogen studied (Karey \& Sirbasku 1988). Vitamin D analogues limit responsiveness of MCF-7 cells to the mitogenic effects of IGF-I (Vink-van Wijingaarden et al. 1996, Xie et al. 1997). Cellular effects of IGF-I are initiated by binding to the type I IGF receptor (IGF-IR) and the interaction between IGF-I and IGF-IR is modulated by a family of IGF binding proteins (IGFBPs). The IGFBPs act by either enhancing or by inhibiting the actions of IGFs (DeMellow \& Baxter 1988, Cohen et al. 1993).
Human IGFBP-3 is a primary modulator of IGF-I actions by preventing IGF-I binding to its receptor and inhibiting IGF-I signalling pathways (Buckbinder et al. 1995). IGFBP-3 has been shown to inhibit the proliferation of oestrogendependent and -independent breast cancer cells (Oh et al. $1993 a$, Pratt \& Pollak 1996) and its expression is increased by ATRA (Fontana $e t$ al. 1991), tumour growth factor $\beta$ (Oh $e t$ al. 1995) and the pure anti-oestrogen ICI 182,780 (Huynh et al. 1996). Antisense oligonucleotide to IGFBP-3 abolishes ATRA-induced growth inhibition in MDA-MB-231 breast cancer cells (Gucev et al. 1996). The Hs578T breast cancer cell line is growth inhibited by retinoids but these cells are unresponsive to IGF-I. However, growth inhibitory effects of retinoids are associated with increased expression of IGFBP-3 which has been postulated directly to inhibit cell growth independently of IGF-I signalling pathways (Oh et al. 1993b). In order to further evaluate the association between modulation of IGF-I signalling pathways and vitamin D-induced growth inhibition of breast cancer cells, we have determined the effects of two vitamin D analogues, EB1089 and CB1093, on growth and IGFBP-3 expression in MCF-7 and Hs578T cells.

\section{Materials and Methods}

\section{Compounds}

Vitamin D compounds $1,25(\mathrm{OH})_{2} \mathrm{D}_{3}, \mathrm{CB} 1093$ and EB1089 (Mathiasen et al. 1993) were received as gifts from Leo Pharmaceutical Products, Ballerup, Denmark and 9-cis RA from Hoffmann-La Roche, Nutley, New Jersey, USA. All compounds were dissolved in absolute ethanol and the final 
concentration of ethanol in tissue culture medium did not exceed $0.1 \%$.

\section{Peptides}

Human recombinant IGF-I (R\&D Systems, Abingdon, Oxon, UK) was diluted in $10 \mathrm{mM}$ hydrochloric acid. Human recombinant IGFBP-3 (Upstate Biotechnology, Lake Placid, NY, USA) was diluted in $10 \mathrm{mM}$ acetic acid. Tissue culture reagents were obtained from Gibco (Paisley, Scotland, UK). All other reagents were analytical grade and obtained from Sigma Chemical Co (Poole, Dorset, UK).

\section{Cells and culture conditions}

MCF-7 human breast cancer cells were routinely maintained in Dulbecco's modification of Eagle's minimal essential medium (DMEM), supplemented with $100 \mathrm{U}$ penicillin $/ \mathrm{ml}, 100 \mu \mathrm{g}$ streptomycin $/ \mathrm{ml}$ and $5 \%$ fetal calf serum (FCS) at $37^{\circ} \mathrm{C}$ with a humidified atmosphere of $5 \% \mathrm{CO}_{2}$. Hs578T cells were routinely maintained under the same conditions. For growth experiments, MCF-7 cells were trypsinized and $1 \times 10^{4}$ cells were plated in 48 well plates in $0.5 \mathrm{ml}$ of growth medium (R.p.m.I 1640 medium containing $2.5 \%$ charcoal-stripped fetal calf serum (SFCS) with the above mentioned supplements). Cells were cultured for $65-68 \mathrm{~h}$ before treatment with IGF-I, vitamin $\mathrm{D}$ derivatives or other test compounds in R.p.m.I 1640 medium containing 1\% SFCS for 3-10 days with a medium change every 2-3 days. Control cultures were incubated in medium containing vehicle alone. Hs578T cells were incubated in R.p.m.I medium containing $0.1 \%$ bovine serum albumin (BSA) and the vitamin D derivatives, retinoids or ethanol vehicle.

\section{Determination of cell proliferation}

On selected days after removal of the incubation medium, the cell monolayer was washed twice with phosphate buffered saline (PBS). Cells were fixed and stained by adding $0.5 \mathrm{ml}$ $0.5 \%$ crystal violet stain in $25 \%$ methanol for $10 \mathrm{~min}$. After washing with distilled water, cultures were air-dried and incorporated dye was eluted with $0.1 \mathrm{M}$ sodium citrate in $50 \%$ ethanol and cell number determined as previously described (Wosikowski et al. 1993).

\section{Preparation of conditioned medium (CM)}

MCF-7 and Hs578T cells were seeded into 24 well plates and grown for 2-3 days in serum containing medium and cell cultures were washed three times with serum-free medium. Cells were then incubated in serum-free R.p.m.I medium containing $0.1 \% \mathrm{BSA}$ in the presence or absence of the test compounds for various times as indicated in the text. Conditioned media (CM) were collected and centrifuged at $1000 \mathrm{~g}$ for $10 \mathrm{~min}$ to remove all cell debris. The harvested $\mathrm{CM}$ from triplicate wells within each experiment were pooled and stored at $-20^{\circ} \mathrm{C}$ until assay.

\section{Western ligand blotting}

Ligand and immunoblotting were performed as previously described (Coulson et al. 1991, Cwyfan-Hughes et al. 1995). Briefly, proteins from $\mathrm{CM}$ were concentrated 10-fold using Millipore Ultrafree-MC filter units, separated by $12 \%$ SDS-polyacrylamide gel electrophoresis and transferred onto a nylon membrane. This was then probed with an equal mixture of iodinated IGF-I and -II, washed, dried and exposed to X-ray film. The same membrane was then incubated with polyclonal antiserum to IGFBP-3 (SCH-2/6 at 1:15000 dilution) overnight at room temperature. Following removal of excess unbound antibody, an anti-rabbit antibody conjugated to peroxidase (1:10000 dilution) was added for $1 \mathrm{~h}$. Binding of the peroxidase conjugate was visualised using enhanced chemiluminescence according to the manufacturer's instructions (Amersham International, Buckinghamshire, UK). The volume of sample loaded was normalized for mean cell number for each treatment group.

\section{Radioimmunoassay}

The levels of IGFBP-3 in CM were measured using a radioimmunoassay previously described (Yateman et al. 1993).

\section{Statistical methods}

Data were analysed by ANOVA using Statview program (Abacus Concept Inc, Berkeley, CA, USA).

\section{Results}

MCF-7 cells were incubated for 3,7 and 10 days in the presence of $30 \mathrm{ng} / \mathrm{ml}$ IGF-I alone or in combination with $10 \mathrm{nM}$ $\mathrm{EB} 1089$, $\mathrm{CB} 1093$ or $1,25(\mathrm{OH})_{2} \mathrm{D}_{3}$. Inhibition of IGF-Istimulated cell growth was observed with the vitamin $D$ analogues but the same concentration of $1,25(\mathrm{OH})_{2} \mathrm{D}_{3}$ was ineffective in limiting responsiveness of cells to IGF-I (Fig. 1a). The effect of human recombinant IGFBP-3 on MCF- 7 cell growth was tested by incubating cells for 7 days in the presence of IGFBP-3 $(0-235 \mathrm{ng} / \mathrm{ml})$ before assessment of cell growth by crystal violet assay. IGFBP-3 inhibited cell growth in a dose-related manner such that $70 \%$ inhibition was achieved at a concentration of $235 \mathrm{ng} / \mathrm{ml}$ (Fig. 1b). We next determined the profile of expression of IGFBPs present in CM from control cultures and MCF-7 cells treated with synthetic vitamin $\mathrm{D}$ analogues by Western ligand blotting. Basal CM showed three major proteins corresponding to IGFBPs 2, 3 and 4 (Fig. 1c lane a). Immunoblotting confirmed the identity of the $\sim 41 \mathrm{kD}$ species as IGFBP-3 (data not shown). Increases in the accumulation of IGFBP-3 in CM from MCF-7 cells treated with EB1089 and CB1093 (1-100 nM)) were observed after 3 days as assessed by Western ligand blots (Fig. 1c).

Unlike MCF-7 cells, Hs578T breast cancer cells were unresponsive to the mitogenic effect of IGF-I over the concentration range $1-150 \mathrm{ng} / \mathrm{ml}$ and for up to 7 days of treatment (data not shown). We have previously demonstrated 

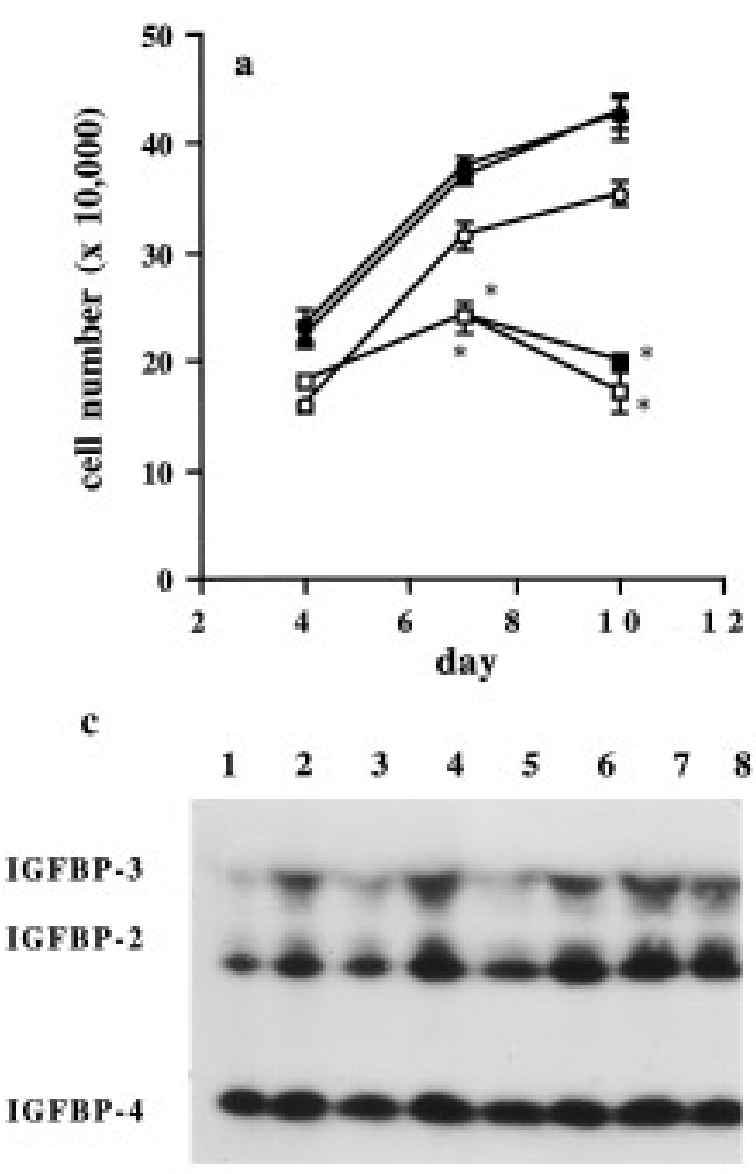
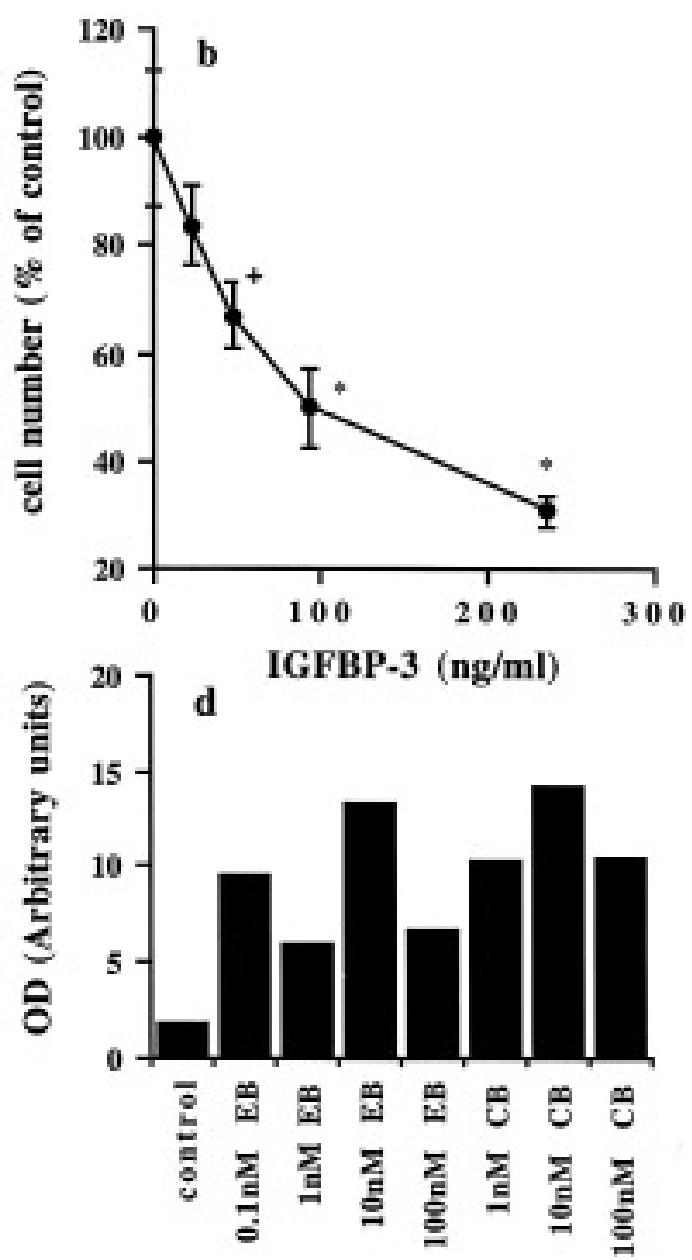

Figure 1 Effects of vitamin D analogues on growth and IGFBP expression in MCF-7 cells. (a) MCF-7 cells were incubated in multiwell plates with ethanol vehicle $(O), 30 \mathrm{ng} / \mathrm{ml}$ human recombinant IGF-I alone (O) or IGF-I together

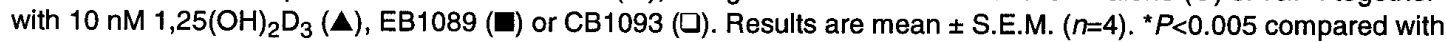
IGF-I alone. (b) Inhibition of MCF-7 cell growth by increasing concentrations of human recombinant IGFBP-3 for 7 days. ${ }^{+} P<0.05,{ }^{*} P<0.005$ compared with vehicle-treated control cultures. (c) Western-ligand blot of concentrated $\mathrm{CM}$ from cells cultured with vehicle (lane 1), 0.1-100 nM EB1089 (lanes 2-5) and CB1093 (1-100 nM, lanes 6-8) for 3 days. (d) Relative IGFBP-3 levels by scanning densitometry.

that Hs578T cells express specific receptors for $1,25(\mathrm{OH})_{2} \mathrm{D}_{3}$ (Colston et al. 1982) and our present studies demonstrate that these cells are inhibited in their growth by the vitamin D analogues EB1089 and CB1093 (Fig. 2a). Western ligand blots demonstrated that IGFBP-3 was the major binding protein secreted by Hs578T cells (Fig. 2c). Immunoblotting confirmed the identity of this protein as IGFBP-3. As expected, accumulation of IGFBP-3 in conditioned medium was increased in cultures treated with ATRA as well as 9-cis RA (Fig. $2 \mathrm{c}$ lanes 5 and 6). However, marked increases in IGFBP-3 secretion were also observed in cultures treated with the vitamin D analogues EB1089 and CB1093 (Fig. 2b and Fig. 2c lanes 2 and 4). Both the analogues produced an approximately 7-fold increase in IGFBP-3 accumulation in CM collected after
3 days treatment with the vitamin $\mathrm{D}$ derivatives. Effects of $1,25(\mathrm{OH})_{2} \mathrm{D}_{3}$ were less marked (Fig. 2b). Cotreatment of Hs578T cells with $10 \mathrm{nM} \mathrm{EB1089}$ and $100 \mathrm{nM}$ 9-cis RA led to augmented effects on cell growth (Fig. 3a) and IGFBP-3 accumulation in $\mathrm{CM}$.

Fig. $3 \mathrm{~b}$ shows the increase in IGFBP-3 levels asassessed by RIA in cotreated cells relative to control cultures. Significant effects on growth inhibition were seen after 3 days treatment with EB1089 and 9-cis RA in combination at which time a 3-fold increase in IGFBP-3 levels in CM was seen.

In cultures treated with EB1089 alone, the time course of change in IGFBP-3 accumulation was slower than in cotreated cultures but the magnitude of increase in IGFBP-3 levels was similar by 7-10 days treatment. $100 \mathrm{nM}$ 9-cis RA 

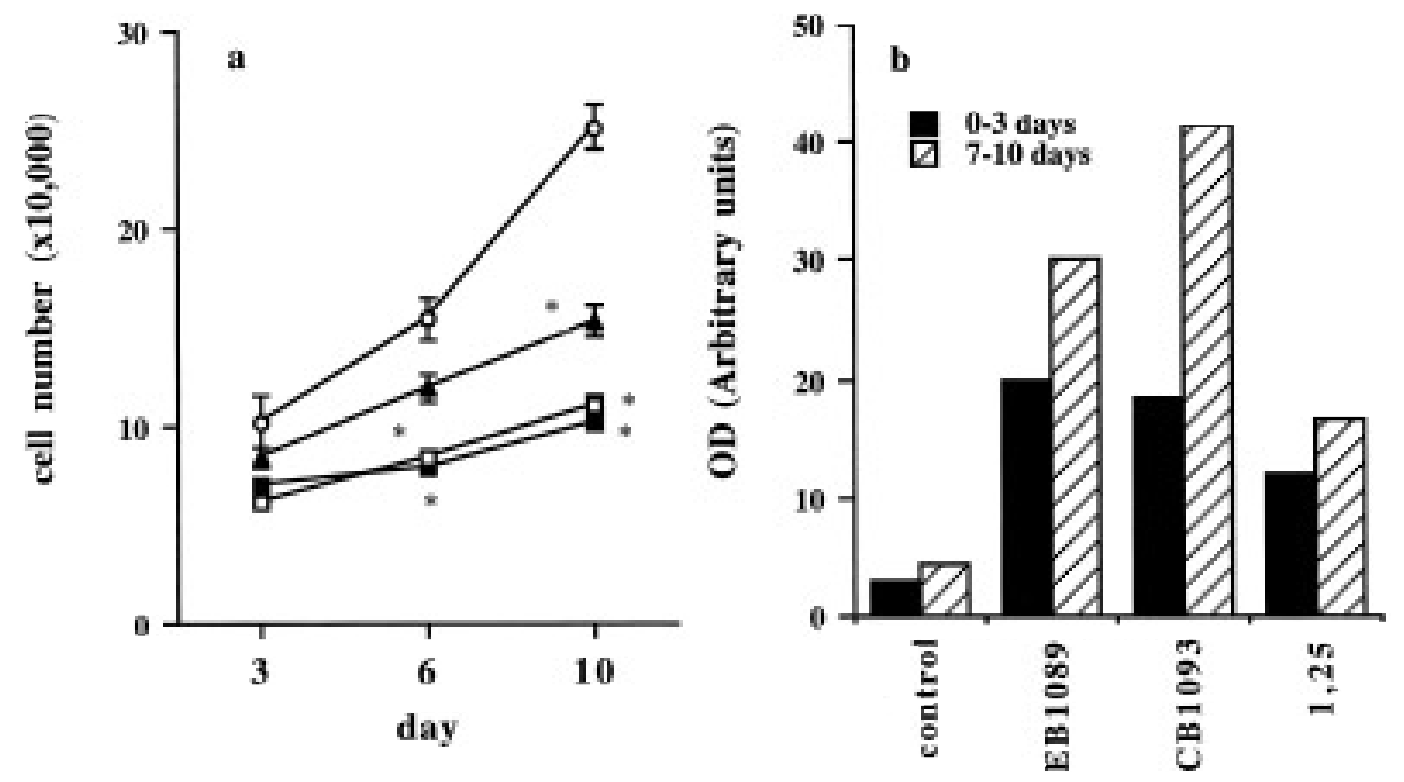

c
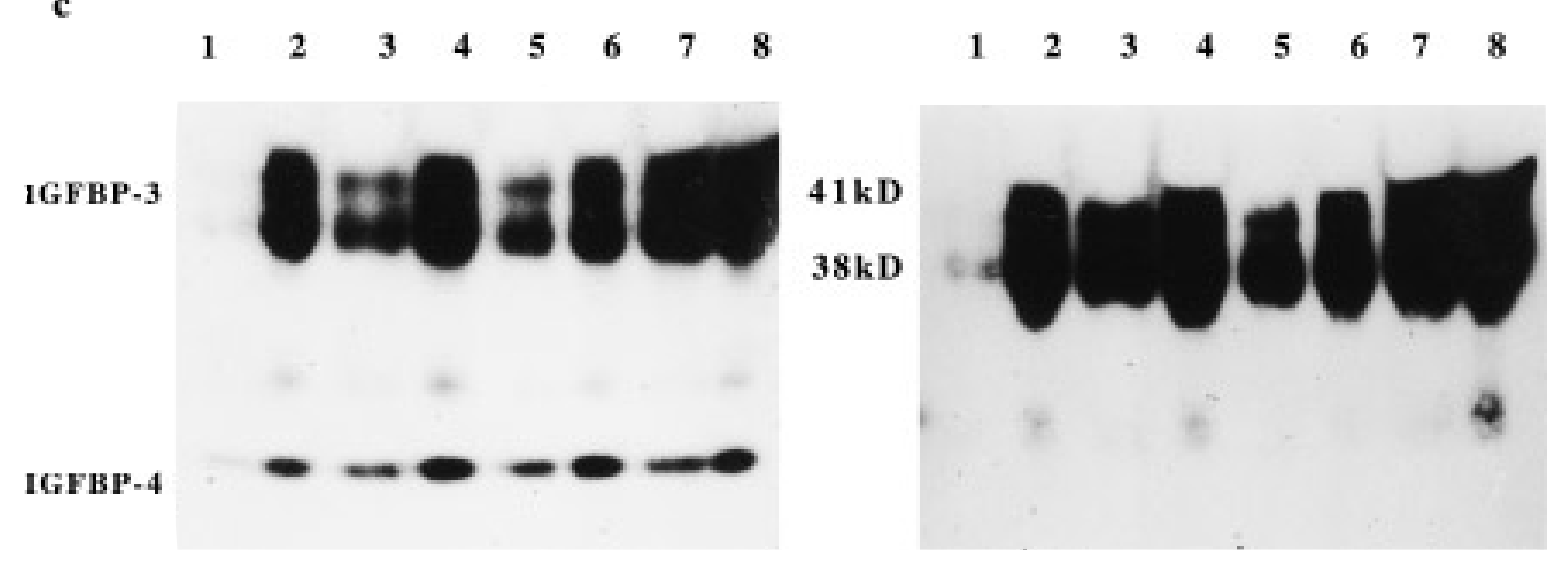

Figure 2 Effects of vitamin D analogues on growth and IGFBP expression in Hs578T cells (a) Effects of vitamin D analogues on cell growth. Hs578T cells were incubated with ethanol vehicle $(\mathrm{O}), 10 \mathrm{nM} 1,25(\mathrm{OH})_{2} \mathrm{D}_{3}(\mathbf{A}), 10 \mathrm{nM} E \mathrm{~B} 1089(\square)$ or $10 \mathrm{nM}$ CB1093 (D). Cell proliferation was assessed after 3,6 and 10 days of treatment. Results are mean $\pm S . E . M .(n=4) .{ }^{*} P<0.005$ compared with vehicle-treated cultures. (b) Relative IGFBP-3 levels by scanning densitometry of Western ligand blots of concentrated CM collected from cultures treated with $10 \mathrm{nM}$ vitamin $\mathrm{D}$ derivatives for up to 10 days. $\mathrm{CM}$ collected for days $0-3$ (solid bars) or 7-10 (hatched bars) of treatment. (c) Western-ligand blot (left) and immunoblot with anti-IGFBP-3 antibody (right) of concentrated $\mathrm{CM}$ from cells cultured for 10 days with: ethanol vehicle (lane 1), $10 \mathrm{nM}$ EB1089 (lane 2), $10 \mathrm{nM}$ $1,25(\mathrm{OH})_{2} \mathrm{D}_{3}$ (lane 3), $10 \mathrm{nM} \mathrm{CB} 1093$ (lane 4), $100 \mathrm{nM}$ ATRA (lane 5), $100 \mathrm{nM}$ 9-cis RA (lane 6), EB1089 and ATRA (lane 7), EB1089 and 9-cis RA (lane 8). CM collected for days 7-10 of treatment.

alone induced only a modest increase in IGFBP-3 over this period.

\section{Discussion}

Insulin-like growth factors are believed to play an important role in the development and growth of breast tumours (Cullen et al. 1990, Osbourne et al. 1990, Rosen et al. 1991). The mitogenic actions of IGF-I are initiated following binding to its membrane receptor and the interaction between IGF-I and IGF-IR is modulated by a family of at least 7 related IGFBPs which have a tissue specific pattern of expression and which may potentiate or, more usually, inhibit the actions of IGF- 1 by preventing receptor interaction. In human breast cancer cell lines, the pattern of IGFBP expression is correlated with oestrogen receptor status with ER positive cells producing 

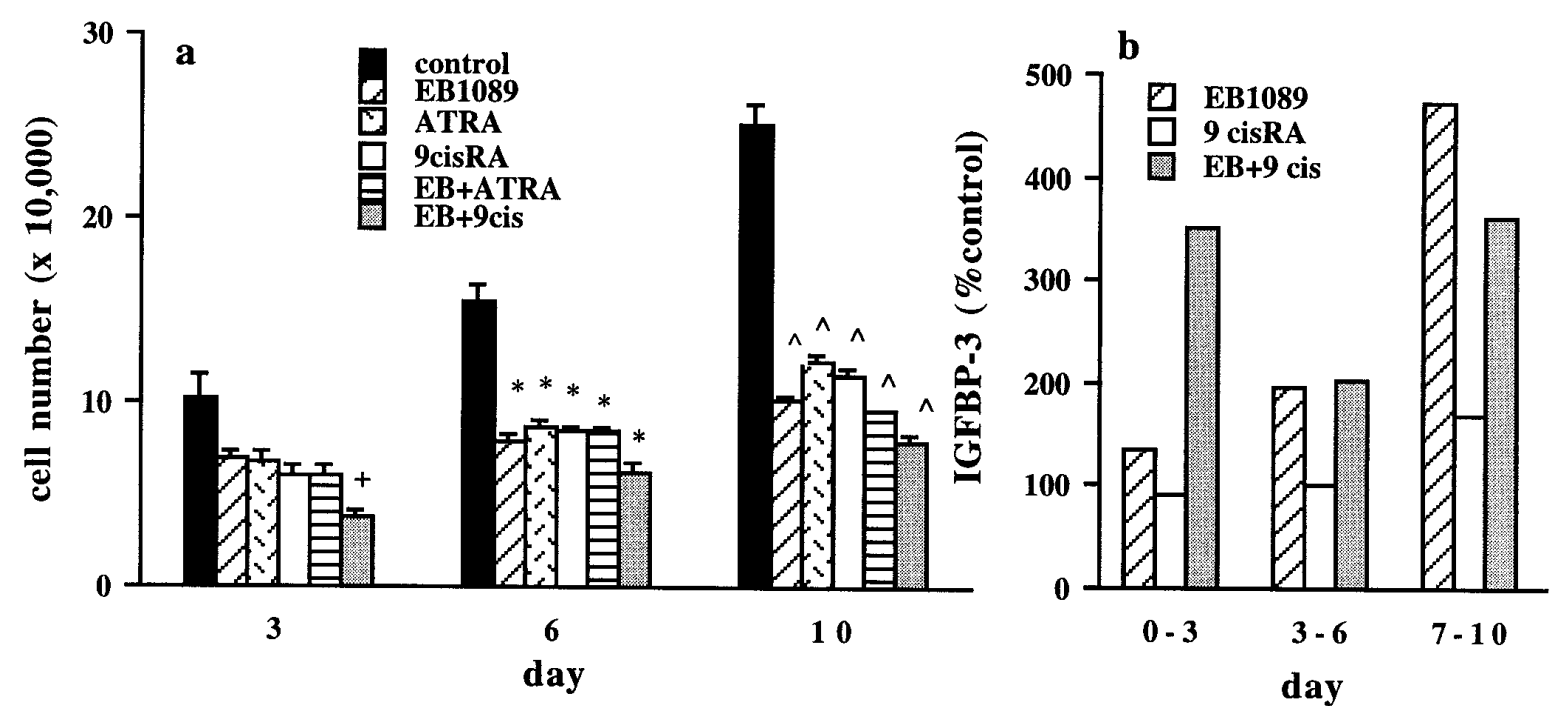

Figure 3 Effects of EB1089 and retinoids on growth and IGFBP-3 expression in Hs578T cells. Cells were cultured for up to 10 days with ethanol vehicle, $10 \mathrm{nM}$ EB1089, $100 \mathrm{nM}$ ATRA, $100 \mathrm{nM} 9$-cis RA or combinations of these agents. (a) Cell number was quantitated by crystal violet assay. Results are means \pm S.E.M. ${ }^{+} P<0.01,{ }^{*} P<0.005, \wedge P<0.001$ compared with ethanol vehicle-treated cultures. (b) CM was collected from cultures treated with $10 \mathrm{nM}$ EB1089, $100 \mathrm{nM}$ 9-cis RA and these two agents in combination at days $0-3,3-6$ and 7-10 of treatment and IGFBP-3 concentration (ng/mI) determined by RIA. Results were adjusted for mean cell number in replicate cultures from each treatment group and are expressed as \% of respective control cultures. Mean concentrations of IGFBP-3 in CM from control cultures were 41.1, 64.5 and $62.1 \mathrm{ng} / \mathrm{ml}$ at 3,6 and 10 days of culture respectively.

IGFBP-2 as the major form whereas ER negative cells secrete mainly IGFBP-3. IGFBP-3 has been shown to inhibit the proliferation of both oestrogen dependent and independent breast cancer cells. As well as inhibiting IGF-I signalling, IGFBP-3 may have direct anti-proliferative activity as has been suggested by studies with the Hs578T breast cancer cell line which is unresponsive to IGF-I (Oh et al. 1993a) and expresses low or undetectable levels of IGF-IR (our unpublished observations). In this study we have demonstrated that two synthetic vitamin D analogues, EB1089 and CB1093, inhibited the growth of Hs578T cells as well as MCF-7 cells. In both cell lines, inhibition of cell growth was associated with increased production of IGFBP-3. It has previously been demonstrated that the potent inhibitory effects of the anti-estrogen ICI 182.780 are associated with increased secretion of IGFBP-3 by the cells (Huynh et al. 1996) and an association between growth inhibition by ATRA and modulation of IGFBP-3 has been demonstrated in both Hs578T and MCF-7 cells (Fontana et al. 1991). Our present findings indicate that effects of vitamin $\mathrm{D}$ analogues on breast cancer cells may be mediated in part by reduction in IGF-I responsiveness through increased expression of inhibitory binding proteins such as IGFBP-3. However, in comparison to effects in Hs578T cells, the magnitude of increase in IGFBP-3 expression in MCF-7 cells in response to vitamin $\mathrm{D}$ analogues was found to be modest and levels of the binding protein accumulating in media conditioned by the cells were low and beneath the detection limit of our RIA (which detects concentrations of IGFBP-3 greater than $16 \mathrm{ng} / \mathrm{ml}$ ).

We would speculate that, in Hs578T cells, increased production and secretion of IGFBP-3 plays a role in the growth inhibitory effects of vitamin $D$ analogues which we have observed in this IGF-I-unresponsive cell line. However in MCF-7 cells, which produce smaller quantities of IGFBP-3 under basal conditions, although the expression of IGFBP-3 is increased by vitamin $\mathrm{D}$ analogues, the level of protein secretion is low and may only exert minimal effects on cell growth. Decreased expression of IGF-IR in response to vitamin $\mathrm{D}$ analogues (Xie et al. 1997) or changes in the production of other inhibitory IGFBPs such as IGFBP-5 (Rozen et al. 1997) may also play a role in mediating the observed effects of vitamin D analogues on MCF-7 cell growth and IGF-I responsiveness. In breast cancer cells, vitamin $\mathrm{D}$ analogues may directly regulate IGFBP-3 gene expression as has been suggested for ATRA (Adamo et al. 1992). Alternatively, effects may be mediated via changes in p53. The gene encoding IGFBP-3 is induced by wild-type p53 (Buckbinder $e t$ al. 1995). We have previously shown that the vitamin $D$ analogue EB1089 increases p53 protein expression in MCF-7 cells and that cotreatment with 9-cis RA enhances this effect (James et al. 1995). Furthermore, vitamin D analogues alone (Welsh 1994, James et al. 1996 ) and in combination with 9-cis RA (James et al. 1995) have been shown to induce apoptosis in MCF-7 cells. Attenuation of the cell survival signal generated 
through the IGF-I receptor is a possible mechanism by which vitamin $\mathrm{D}$ derivatives could promote active cell death.

\section{Acknowledgements}

We are grateful to Dr Lise Binderup, Leo Pharmaceutical Products Denmark for providing the vitamin D compounds and Dr Milan Uskokovic, Hoffman-La Roche for 9-cis retinoic acid. We thank Kate Meadows for carrying out IGFBP-3 radioimmunoassays. This work was supported in part by the Pathological Research Fund, St George's Hospital Medical School and the Medical Research Council.

\section{References}

Abe J, Nakano T, Nishii Y, Matsumoto T, Ogata E \& Ikeda K 1991 Endocrinology 129 832-837.

Adamo ML, Shao ZM, Lanau F, Chen JC, Clemmons DR, Roberts CT, LeRoith D \& Fontana JA 1992 Endocrinology 131 1858-1860.

Buckbinder L, Talbott R, Velasco-Miguel S, Tanenaka BH, Seizinger BR \& Kley N 1995 Nature 377 646-649.

Cohen P, Lamson G, Okajima T \& Rosenfeld RG 1993 Molecular Endocrinology 7 380-386.

Colston K, Colston MJ, Fieldsteel HA \& Feldman D 1982 Cancer Research 42 856-859.

Colston KW, Mackay AG, James SY, Binderup L, Chander S \& Coombes RC 1992 Biochemical Pharmacology 44 2273-2280.

Coulson VJ, Wass JAH, Abdulla AF, Cotterill AM \& Holly JMP 1991 Growth Regulation 1 119-124.

Cullen KJ, Yee D, Sly WS, Perdue J, Hampton B, Lippman ME \& Rosen N 1990 Cancer Research 50 48-53.

Cwyfan-Hughes SC, Johnson MR, Heinrich G \& Holly JMP 1995 Journal of Endocrinology 147 517-524.

De Mellow JSM \& Baxter RC 1988 Biochemical \& Biophysical Research Communications 156 199-204.

Fontana JA, Burrows-Mezu A, Clemmons DR \& LeRoith D 1991 Endocrinology 128 1115-1122.
Gucev ZS, Oh Y, Kelley KM \& Rosenfeld RG 1996 Cancer Research 56 1545-1550.

Huynh H, Yang X \& Pollak M 1996 Journal of Biological Chemistry 271 1016-1021.

James SY, Mackay AG \& Colston KW 1995 Journal of Molecular Endocrinology 14 391-394.

James SY, Mackay AG \& Colston KW 1996 Journal of Steroid Biochemistry and Molecular Biology 58 391-401.

Karey KP \& Sirbasku DA 1988 Cancer Research 48 4083-4092.

Mathiasen IS, Colston KW \& Binderup L 1993 Journal of Steroid Biochemistry and Molecular Biology 46 365-371.

Oh Y, Muller HL, Lamson G \& Rosenfeld RG 1993a Journal of Biological Chemistry 268 14964-14971.

Oh Y, Muller HL, Pham H \& Rosenfeld RG 1993 b Journal of Biological Chemistry 268 26045-26048.

Oh Y, Muller HL, Ng L \& Rosenfeld RG 1995 Journal of Biological Chemistry 270 13589-13592.

Osbourne CK, Clemmons DR \& Aretega CL 1990 Journal of Steroid Biochemistry and Molecular Biology 37 805-809.

Pratt SE \& Pollak MN 1994 Biochemical and Biophysical Research Communications 198 292-297.

Rosen N, Yee D, Lippman ME, Paik S \& Cullen KJ 1991 Cancer Treatment Research 18 S55-S60.

Rozen F, Yang X-F, Huynh H \& Pollak M 1997 Journal of the National Cancer Institute 89 652-656.

Vink-van Wijngaarden T, Pols HAP, Buurman CJ, Birkenhager JC \& van Leeuwen JPTM 1996 European Journal of Cancer 32A 842-848.

Welsh JE 1995 Biochemical and Cellular Biology 72 537-545.

Wosikowski K, Kung W, Hasmann M, Loser R \& Eppenberger U 1993 International Journal of Cancer 53 290-297.

Xie SP, James SY \& Colston KW 1997 Journal of Endocrinology 154 495-504.

Yateman ME, Claffey DC, Cwyfan-Hughes SC, Frost VJ, Wass JAH \& Holly JMP 1993 Journal of Endocrinology 137 151-159. 